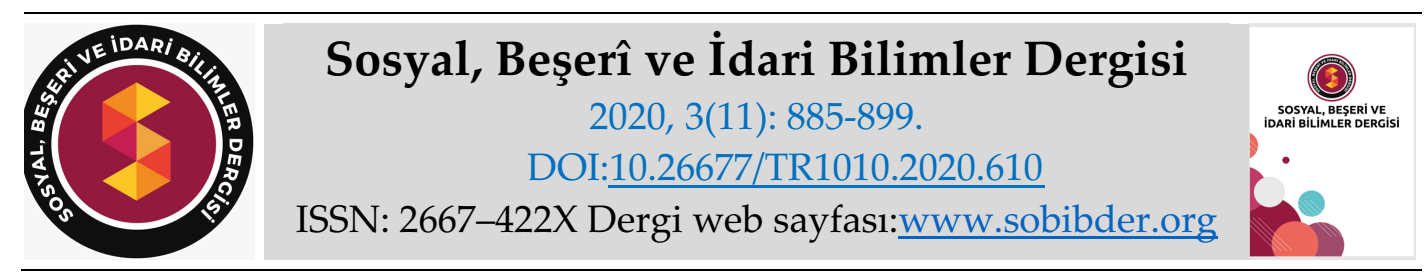

ARAȘTIRMA MAKALESI

\title{
Yeni Nesil İşte Nasıl Güdüleniyor? İş Motivasyonu Ekseninde X-Y Kuşaklararası Farklılaşma
}

Doç. Dr. Aykut GÖKSEL, Ankara Hacı Bayram Veli Üniversitesi, İktisadi ve İdari Bilimler Fakültesi, Ankara, e-posta: aykut.goksel@hbv.edu.tr ORCID: https://orcid.org/0000-0003-2780-8117

Batuhan AYAN, Doktora Öğrencisi, Ankara Hacı Bayram Veli Üniversitesi, Lisansüstü Eğitim Enstitüsü, Ankara, e-posta: batuhan.ayan@hbv.edu.tr

ORCID: https://orcid.org/0000-0002-4105-1723

Öz

İş hayatında aktif olarak çalışan X kuşağı ve $Y$ kuşağı, hayat şartları ve yetiştirilme tarzlarından kaynaklanan farklılıklara sahiptir. Bu farklılıklar iş ortamındaki motivasyon kaynaklarında farklılaşmalara yol açabilmektedir. Bu çalışma, kamu veya özel sektörde çalışan $X$ ve $Y$ kuşaklarına mensup bireylerin iş motivasyonlarında farklılaşma olup olmadığını incelemek amacıyla yapılmıştır. Araştırma kapsamında 157 özel sektör ve 180 kamu sektöründe olmak üzere toplam 337 kişiye anket uygulanmıştır. Araştırmada, Gagne vd., (2014) tarafından yedi dilde (Fransızca, İngilizce, Felemenkçe, Norveççe, Almanca, Endonezya dili ve Çince) ve dokuz ülkede (Kanada, Belçika, Fransa, Senegal, Birleşik Krallık, Norveç, İsviçre, Çin ve Endonezya) geçerlemesi yapılan ve Çivilidağ ile Şekercioğlu tarafından Türk kültürüne uyarlaması gerçekleştirilen çok boyutlu iş motivasyonu ölçeği kullanılmıştır. Yapılan analizlerde $Y$ kuşağının içe yansıtılan düzenleme, kişisel düzenleme ve içsel motivasyon düzeyleri $X$ kuşağına göre daha yüksek olarak bulunmuştur. Motive olmama ve dışsal düzenleme alt boyutları ile $X$ ve $Y$ kuşağı arasında anlamalı bir ilişki bulunamamıştır.

Anahtar Kelimeler: X Kuşağı, Y Kuşağı, Motivasyon, İş Motivasyonu.

Makale Gönderme Tarihi: 02.08.2020

Makale Kabul Tarihi: 03.11.2020

\section{Önerilen Atıf:}

Göksel, A. ve Ayan, B. (2020). Yeni Nesil İşte Nasıl Güdüleniyor? İş Motivasyonu Ekseninde X-Y Kuşaklararası Farklılaşma, Sosyal, Beşeri ve İdari Bilimler Dergisi, 3(11): 885-899.

C 2020 Sosyal, Beşerî ve İdari Bilimler Dergisi. 


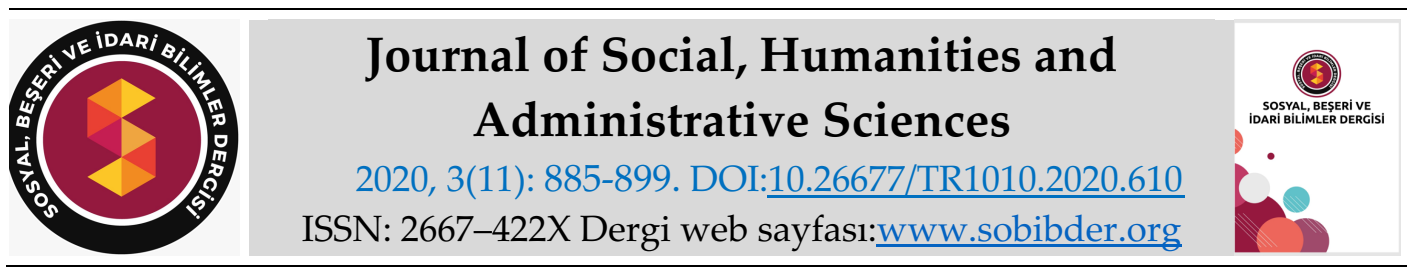

$\underline{\text { RESEARCH PAPER }}$

\title{
How Is the New Generation Motivated at Work? Differentiation Between X-Y Generations on The Axis of Business Motivation
}

Associate Prof. Dr. Aykut GÖKSEL, Ankara Hacı Bayram Veli University, Faculty of Economics and Administrative Sciences, Ankara, e-mail: aykut.goksel@hbv.edu.tr

ORCID: https://orcid.org/0000-0003-2780-8117

Batuhan AYAN, Ph.D Student, Ankara Hacı Bayram Veli University, Graduate Education Institute, Ankara, e-mail:batuhan.ayan@hbv.edu.tr

ORCID: https://orcid.org/0000-0002-4105-1723

\begin{abstract}
Generation $X$ and Generation $Y$, who work actively in business life, have differences arising from living conditions and upbringing. These differences can lead to differences in motivation sources in the business environment. This study was carried out to examine whether there is a difference in the work motivation of individuals belonging to the $X$ and $Y$ generations working in the public or private sector. Within the scope of the research, a total of 337 people was surveyed, including 157 private and 180 public sectors. In the study, it was validated by Gagne (2014) in seven languages (French, English, Dutch, Norwegian, German, Indonesian and Chinese) and nine countries (Canada, Belgium, France, Senegal, United Kingdom, Norway, Switzerland, China and Indonesia) and Çivilidağ and Şekercioğlu adapted the multi-dimensional work motivation scale to Turkish culture. In the analyzes, introjected regulation, identified regulation and inner motivation levels of Generation $\mathrm{Y}$ were found higher than generation X. No significant relationship was found between the amotivation and external regulation sub-dimensions and the $X$ and $Y$ generation.
\end{abstract}

Keywords: X Generation, Y Generation, Motivation, Work Motivation.

Received: 02.08 .2020

Accepted: 03.11.2020

\section{Suggested Citation:}

Göksel, A. and Ayan, B. (2020). How Is the New Generation Motivated at Work? Differentiation Between X-Y Generations on The Axis of Business Motivation, Journal of Social, Humanities and Administrative Sciences, 3(11): 885-899.

(c) 2020 Sosyal, Beşerî ve İdari Bilimler Dergisi. 


\section{Gíriş}

Günümüz iş hayatında "Bebek Patlaması Kuşağı", "X Kuşağı" ve "Y Kuşağı" olmak üzere 3 kuşak aktif olarak birlikte çalışmaktadır (Aydın ve Başol, 2014:2). Ancak kuşaklar, yetişme tarzları ve içerisinde bulundukları ortam değişikliklerinden kaynaklanan farklılıklara sahiptirler (Adıgüzel vd., 2014:166). Bu farklılıklar, bir kuşağın olaylara verdiği tepkiler, kendilerini ifade etme stilleri, hayalleri, talepleri, amaçları ve motivasyon kaynakları ile diğer kuşaklardan farklılaşmalarına neden olabilmektedir (Altınok, 2019:2). Bu durum gerek çalışanlar açısından gerekse çalışanlarını ortak bir hedefe yönlendirmek için çaba gösteren yöneticiler açısından zaman zaman sorun oluşturabilmektedir. Ancak, her kuşağın nasıl motive edilmek istendiğini anlamak bir çözüm yolu sunabilir.

Her bireyin motivasyon kaynağı, içinde bulunduğu duruma ve ortam şartlarına göre farklılık gösterebilir. Ancak, belirli bir dönemde doğmuş, benzer bir ortamda yetişmiş, ortak inanç ve davranışları paylaşma eğiliminde olan aynı kuşağa mensup bireylerin iş ortamındaki motivasyon kaynakların genel olarak benzer özellikler göstermesini beklemekteyiz. Başka bir ifade ile $X$ ve $Y$ kuşaklarının iş motivasyonu kaynaklarının birbirinden farklı olduğu değerlendirilmektedir. $\mathrm{Bu}$ noktada çalışmadaki amaç, $X$ ve $Y$ kuşaklarının iş motivasyonlarında farklılaşma olup olmadığını incelemektir.

Literatürde iş motivasyonu ile örgütsel bağll1ık (Apridar,2018; Orpen,1997; Çakar ve Ceylan,2005; Hatipoğlu ve Dündar,2018), örgütsel vatandaşlık (Apridar, 2018; Dharma, 2017), örgütsel sessizlik (Göksel ve Güneş, 2017), iş tasarımı (Al-Musadieq, 2018), örgüt kültürü (Al-Musadieq, 2018), iş tatmini (Eskildsen vd., 2004; Gökkaya ve Türker, 2018; Özcan ve Bayarçelik, 2020; Saracel vd., 2016; Hatipoğlu ve Dündar, 2018), işe bağlllık (Altınok, 2019), performans (Dharma, 2017; Orpen, 1997) ve verimlilik (Hong vd., 1995) arasındaki ilişkileri inceleyen çalışmalar sıkça yer almaktadır. Ancak, iş motivasyonunun kuşaklar arası farklılaşmasını inceleyen çalışmaların az olduğu görülmüştür. Bu nedenle çalışmanın, literatüre önemli bir katkıda bulunması beklenmektedir.

\section{MOTIVASYON ve ISŞ MOTIVASYONU KAVRAMLARI}

Motivasyon kelimesi, hareket etmek anlamına gelen Latince "movere" kelimesinden türetilmiştir (Kreitner ve Kinicki, 1988). "Motivasyon" terimi, bireyin uyarılmasın, belirli bir eyleme yönlendirilmesini, davranışların kalıcılığının güçlendirilmesini ve niyetini etkileyebilecek psikolojik bir süreç olarak tanımlanmaktadır (Rahman, 2017:2). Luthans 1998'de motivasyonun davranış ve performansı uyandıran, enerjilendiren, yönlendiren ve sürdüren bir süreç olduğunu ileri sürmüştür. Yani motivasyon, insanları harekete geçmeye ve istenen bir görevi yerine getirmeye teşvik etme sürecidir (Acar, 2014:13). Motivasyon, Robbins (1993) tarafından ise "bazı bireysel ihtiyaçları karşılama çabasıyla koşullandırılmış, örgütsel hedeflere yüksek düzeyde çaba gösterme isteği" olarak tanımlanmaktadır (Al-Araimi, 2002:208). Motivasyonu en basit şekilde "birisinin belirli bir hedefe yönelik bir şekilde hareket etmesi için temel sağlayan bir dizi davranış" olarak tanımlamak mümkündür (Dharma, 2017:8).

Motivasyon doğrudan gözlemlenemez fakat motivasyonu kişinin davranışından çıkarmak mümkündür. Psikologlar motivasyonu üç davranışsal özellik olarak tanımlamışlardır. Bunlar; Yön. Çalışanların motivasyon düzeyi, alternatif eylem tarzları arasında verdikleri kararlara yansır. Çaba ve canlılık. Motivasyonun bir diğer göstergesi ve motivasyonla en sık ilişkilendirdiğimiz, hedefin peşinde gösterilen çabadır. Bu, bir görevin performansıyla ilişkili canlılık ve yoğunlukta kendini gösterir. Ayrıca faaliyete harcanan zaman, iş yükü miktarı ve çalışma hızı ile de gösterilir. Süreklilik. Üçüncü bir gösterge, hedefe ulaşmadaki sürekliliktir. 
Oldukça motive olmuş bir kişi, başarabileceği acı, hayal kırıklığı ve şüpheler karşısında bile bir görevi sürdürür (Dipboye, 2018:104). Fuller vd. (2008), motivasyonu şu şekilde tanımlamaktadır: kişinin belirli bir hedefe ulaşmak için gösterdiği çabaların yoğunluğu, yönü ve devamlılı̆̆ıdır (Kian ve Yusoff, 2012:400). Başka bir ifade ile motivasyon, davranış ve eylemin tüm yönlerini değil, aynı zamanda hareket etme niyetini de ifade eder; davranışı canlandırır ve yönlendirir (Ryan ve Deci, 2000).

Geleneksel motivasyon bakış açısı, hangi neden ve hedeflerin bir davranışa veya eyleme neden olduğuna bağlı olarak iki motivasyon türü arasında ayrım yapmaktır (Ryan ve Deci, 2000). Bu bakış açısına göre, bir kişi dışsal olarak motive edilebilir veya içsel olarak motive edilebilir (Gagne ve Deci, 2005). Nolen ve Nicholls (1993) kavramsal olarak içsel motivasyonu, katılım veya icra etmek için içsel itici güç olarak tanımlamışlardır (Murphy ve Alexander, 2000:10). Başka bir ifade ile içsel motivasyon, gerçekleştirilen bir faaliyette sergilenen davranışın özünde tatmin ve zevk duygularını tecrübe etmenin amaçlandığı bir motivasyon çeşidi olarak tanımlanmaktadır. İçsel İçsel motivasyonu yüksek işgörenler, işlerini eğlenceli, ödüllendirici ve ilginç bulduklarından dolayı çalışmaktadırlar (Çivilidağ ve Şekercioğlu, 2017:145). Dışsal motivasyon ise, ödüller ve onay almak, cezalardan veya eleştirilerden kaçınmak, kişinin benlik saygısını artırmak veya kişisel olarak değerli bir hedefe ulaşmak gibi araçsal nedenlerle faaliyete katılmayı ifade eder (Gagne vd., 2014:2).

Öz belirleme kuramı ise, sadece dışsal ve içsel motivasyondan ziyade birçok farklı motivasyon türünü birbirinden ayıran insan motivasyonunun bir makro teorisidir (Gagne ve Deci, 2005). Öz belirleme kuramı, üç ana motivasyon kategorisi üzerinde durmaktadır. Birincisi motive olmama / güdülenmeme, ikincisi içsel motivasyon ve üçüncüsü dışsal motivasyondur. Öz belirleme kuramı, içselleştirmelerinde farklılık gösteren dışsal motivasyonun farklı alt tiplerini belirtmektedir. İçselleştirme, başlangıçta ödüller veya cezalar gibi dış faktörler tarafından düzenlenen, içsel olarak düzenlenmesi için değere dayalı veya hedefe yönelik bir faaliyete girmeyi ifade eder. Tamamen içselleştirilmemiş olan ilk dışsal motivasyon biçimi dışsal düzenlemedir. Başkaları tarafından verilen ödülleri almak veya cezalardan kaçınmak için bir etkinlik yapmak anlamına gelir. Dışsal motivasyonun bir diğer alt tipi olan içe yansıtılan düzenleme; ego, utanç ve suçluluk gibi içten baskı yapan kuvvetlerin dışında kalan davranışların düzenlenmesini ifade eder. Bu içselleştirme biçimi kontrol olarak deneyimlenir. Son olarak, kişisel düzenleme bir faaliyetin yapılmasını ifade etmektedir (Gagne vd., 2014:2).

Öz belirleme kuramı, motive olmama / güdülenmeme (ör. motivasyon eksikliği) ve motivasyon arasında ayrım yapar. Motive olmama / güdülenmeme, hareket etme niyetine sahip olmamayı içerirken, motivasyon harekete geçme niyetini içermektedir. Motivasyon içinde, öz belirleme kuramı özerk motivasyon ile kontrollü motivasyon arasındaki farklılığı ortaya koymaktadır. Özerk motivasyon, içsel motivasyonu ile iyi içselleştirilmiş dışsal motivasyonu içerir. Böylece, özerk bir şekilde motive olmak, kişinin bir faaliyete olan ilgisiyle motive olmak anlamına gelir. Kontrollü motivasyon ise diş düzenleme ve içe yansitılan düzenlemenin yer aldığı diş motivasyondan oluşur. Böylece, kişinin kontrollü motivasyonunun derecesi; kişinin kendini zorlama hissi derecesini veya kişinin dişsal olasılıklar tarafından baştan çıkarılma derecesini yansitır (Gagne ve Deci, 2005:340).

Öz belirleme kuramı; bir aracı veya kişisel nedensellik duygusu ile karakterize edilen özerk motivasyonu, kişiler arası güçler tarafından kişiyi belirli şekillerde davranmaya zorlanmış veya baskı altında hissetmeyi içeren kontrollü motivasyonla zıtlaştırarak algılanan nedensellik konusunu doğrudan ele almaktadır (Nix vd., 1999:272). Kısaca ifade etmek gerekirse kontrollü motivasyon, dışardan gelen düzenlemeyi ifade ederken özerk motivasyon gerçek öz düzenlemeyi ifade etmektedir (Ryan ve Deci, 2000). Literatürdeki çalışmaların birçoğu motivasyonun bu şekillerini, iş yaşamı da dâhil olmak üzere hayatın farklı alanlarında 
desteklemiştir. Örneğin özerk motivasyon örgütsel bağlllık, mesleki bağlllık ve iş doyumuyla pozitif yönde ilişkili iken kontrollü motivasyon ise iş görenler için olumsuz sonuçlarla (İşten ayrılma niyeti, iş koliklik, tükenmişlik gibi) ilişkilidir (Çivilidağ ve Şekercioğlu, 2017:145).

Tablo 1. Öz Belirleme Kuramı Süreci

\begin{tabular}{|c|c|c|c|c|}
\hline \multirow{2}{*}{ Motive Olmama } & \multicolumn{3}{|c|}{ Dişsal Motivasyon } & \multirow{2}{*}{ İçsel Motivasyon } \\
\hline & $\begin{array}{c}\text { Dişsal } \\
\text { Düzenleme }\end{array}$ & $\begin{array}{l}\text { İçe Yansıtılan } \\
\text { Düzenleme }\end{array}$ & $\begin{array}{c}\text { Kişisel } \\
\text { Düzenleme }\end{array}$ & \\
\hline $\begin{array}{c}\text { Kasıtlı } \\
\text { düzenleme } \\
\text { eksikliği }\end{array}$ & $\begin{array}{c}\text { Ödül ve ceza } \\
\text { koşulu }\end{array}$ & $\begin{array}{l}\text { Özsayg1 } \\
\text { koşulu }\end{array}$ & $\begin{array}{c}\text { Hedeflerin, } \\
\text { değerlerin ve } \\
\text { düzenlemelerin } \\
\text { önemi }\end{array}$ & $\begin{array}{l}\text { Göreve duyulan } \\
\text { ilgi ve keyif }\end{array}$ \\
\hline $\begin{array}{l}\text { Motivasyon } \\
\text { Eksikliği }\end{array}$ & \multicolumn{2}{|c|}{$\begin{array}{c}\text { Kontrollü Motivasyon } \\
\text { Dişarıdan gelen düzenlemeler }\end{array}$} & \multicolumn{2}{|c|}{$\begin{array}{l}\text { Özerk Motivasyon } \\
\text { Öz düzenlemeler }\end{array}$} \\
\hline
\end{tabular}

Kaynak: Gagne ve Deci, 2005:336

Kontrollü motivasyon ve motivasyonsuzluğun aksine, özerk motivasyonun en çok istenen davranışsal, tutumsal ve duygusal sonuçları verdiği araştırmalarda bulunmuştur (Gagne vd.,2014:2).

\section{$X$ ve $Y$ KUŞAKLARI}

Türk Dil Kurumu'na göre kuşak kavramı "yaklaşık yirmi beş otuz yıllık yaş kümelerini oluşturan bireyler öbeği, göbek, nesil, batın, jenerasyon" olarak tanımlanmaktadır (https://sozluk.gov.tr/ ). Tarih felsefesi ve kültür tarihinde ise "kuşak" kavramı yeni bir anlayışta ve yeni bir yaşama duygusunda, yeni biçimlerde birleşen, eskiden belirgin çizgilerle ayrılan bireyler topluluğu olarak ifade edilmektedir (Adıgüzel vd., 2014:169). Scott ve Marshall'a göre ise kuşak, yaklaşık aynı zamanda doğmuş bir toplumun üyelerinden oluşan bir yaş grubu olarak tanımlanmıştır (Akgemci ve Kalfaoğlu, 2018:235). "Kuşak" kelimesi, iki belirli tarih arasında doğan ve demografik özellikler gibi ortak bir kimliğe sahip bir grup insana atıfta bulunur (Rahman, 2017:5).

William Strauss ve Neil Howe (1991) kuşakları tanımlamada; ortak paylaşılan yaş dönemi, yaşanılan dönemin özellikleri (kültür, aile hayatı vb.) ve ortak algılanan üyelik ölçütlerini temel almışlardır (Ekşili ve Antalyalı, 2017:91). Kuşaklar kronolojik olarak Tablo 2'de yer aldığı gibi sıralanmaktadır.

Tablo 2. Kronolojik Kuşak Sınıflandırması

\begin{tabular}{|l|c|}
\hline Kuşak Adı & Dönemi \\
\hline Sessiz Kuşak & $1925-1945$ \\
\hline Bebek Patlaması Kuşağ1 & $1946-1964$ \\
\hline X Kuşağı & $1965-1979$ \\
\hline Y Kuşağı & $1980-2000$ \\
\hline Z Kuşağı & 2000 sonrası \\
\hline
\end{tabular}

Kaynak: Göksel ve Güneş, 2017:810 
Günümüzde iş hayatında en çok yer alan kuşak grupları $X$ ve $Y$ kuşakları olduğu için ve makale konumuz gereği sadece $X$ ve $Y$ kuşakları hakkında bilgiye yer verilmiştir.

X Kuşağı: 1965 -1979 yılları arasında doğan bireylerden oluşan X Kuşağı, çeşitli ekonomik ve sosyal krizlerin yaşandığı bir dönemde dünyaya geldiği için Kayıp Kuşak olarak da adlandırılmaktadır (Akçakanat vd., 2017:141). Sokaklarda yaşanan çatışmalar, protesto gösterileri, boykotlar (Taş ve Kaçar, 2019:648), istikrarsız bir ekonomi, AIDS salgını, soğuk savaşın sona ermesi, organizasyonların ve hükümetlerin karıştığı skandallar gibi pek çok olaya tanıklık etmişlerdir (Bekmezci, 2017:105).

Bu kuşağın en belirgin özelliği gelecek kaygısı taşımaları olmuştur (Metin ve Kızıldağ, 2017:344). Yaşadıkları gelecek kaygısı; bu kuşağı çok çalışmaya, kariyer yapmaya ve daha çok para kazanmaya odaklamıştır (Helvacıoğlu ve Fırın, 2019:205). Bu kuşağı maddi durum motivasyon açısından çok etkilememekle birlikte, paranın eksikliği bazen motivasyon düşüklüklerine neden olmuştur (Saracel vd., 2016:52). X kuşağ1; toplumsal sorunlara karşı duyarlı, iş motivasyonları yüksek (Aydın ve Başol, 2014:3; Keleş, 2011:131), otoriteye saygılıdırlar (Keleş, 2011:131). Ayrıca, odaklandığı ve motive edildiği takdirde son derece iyi çalışırlar (Mert ve Neslihanoğlu, 2020:929). Kendi sorunlarını kendileri çözmeye çalışan ve bu nedenle de kendilerine güvenleri ve iş yapabilirlikleri daha yüksek olan bir kuşaktır (Göksel ve Güneş, 2017:812). Bu kuşak çalışanları esnek, teknolojiyi rahat kullanabilen bir yapıya sahiptirler ve hiyerarşik yapıları tercih ederler (Adıgüzel vd., 2014:173).

Y Kuşağı: Millennials (Milenyum Kuşağı), Generation Next (Gelecek Kuşak), Digital Generation (Dijital Kuşak), Echo Boomers (Eko Patlaması) ve Nexters (Bir Sonrakiler) gibi farklı isimlerle adlandırılmaktadırlar (Adıgüzel vd., 2014:173). 1981-1999 yılları arasında doğan bireylerden oluşan Y kuşağının (Ekşili ve Antalyalı, 2017:92) hangi tarihte doğanları kapsadığı konusunda literatürde görüş farklılığı bulunmaktadır (Göksel ve Güneş, 2017:812). Y kuşağının en belirgin özelliklerinden biri, herhangi bir durum veya sorunla karşılaştıklarında "neden" sorusuna cevap aramaları olduğu ifade edilmektedir. Bu sebeple "Neden Kuşağı" şeklinde de anılmaktadırlar (Akoğlu ve Eroğlu, 2019:223). Bu kuşağın üyeleri, Körfez Savaşı'nın, Irak Savaşı'nın, dünya çapında terör saldırılarının ve doğal afetlerin yaşandığı, internet, Google, MSN, MP3, dijital kameralar ve cep telefonlarının tüm dünyada yaygın hale geldiği bir zamanda yaşamışlardır (Akçakanat vd., 2017:141). Temel karakteristik özellikleri; diğer kuşaklardan daha fazla sorgulamak, düşüncelerini açıkça ifade etmek ve mevcut uygulamaların doğruluğunun kanıtlanmasını istemek şeklinde ifade edilebilir (Bekmezci, 2017:105). Anne ve baba bağımlısı olan Y kuşağı, ebeveynlerinin yoğun ilgisi ve çocuklarıyla yüksek beklentiler içinde olmalarıyla, Y kuşağının kendilerine olan güvenlerini daha da arttırmıştır. Bu kuşak ayrıca daha fazla tüketim temelli düşünen bir kuşaktır (Konakay, 2018:82).

Y kuşağının yaratıcı, sabırdan yana zayıf, sonuç odaklı, aceleci ve iş değiştirme sıklığı nedeniyle çoğu kez sadakatsiz olarak tanımlandığı görülmektedir. Ancak bu kuşağın üyeleri, işleri ile kendilerini ifade etmek, birçok işi aynı anda yürütmek, her şeyi anlamaya çalışmak ve alınacak kararlarda aktif rol oynayarak iş hayatı içerisinde var almaya çalışmaktadır (Metin ve Kızıldağ, 2017:345). Y Kusağı'nın motivasyonu diğer kuşaklara göre farklılık göstermektedir. Y Kuşağı çalışanları aldıkları maaştan çok, sosyal yardımlar, esnek çalışma saatleri gibi manevi olarak da onları tatmin edecek faktörlere odaklanmaktadır (Saracel vd., 2016:53). Y kuşağı çalışanları iyi yönetildikleri takdirde zengin bir yetenek kaynağı olmaktadırlar (Keleş, 2011:131).

Kuşakların görünüm, iş etiği, otoriter görünüm, liderlik tarzı, ilişkileri, bakış açıları ve çeşitli yönleriyle ilgili temel farklılıkları aşağıdaki tabloda yer aldığı gibi ifade edilebilir (Boz ve Berber, 2017:528). 
Tablo 3. Kuşakların İş Hayatındaki Özelliklerinin Karşılaştırılması

\begin{tabular}{|l|l|l|}
\hline & X Kuşağı & Y Kuşağı \\
\hline Görünüm & Şüpheci & Umutlu \\
\hline İş Etiği & Dengeli & Hirslı \\
\hline Otoriter Görünüm & Umursamaz & Rahat / Nazik \\
\hline Liderlik Tarzı & Yetki & $\begin{array}{l}\text { Akademik Başarı / } \\
\text { Uyum İçinde Çalışma }\end{array}$ \\
\hline İlişkiler & Gönülsüz & Vefalı \\
\hline Bakış Açısı & Kendine Güvenen & Kamu İşlerinde Faaliyet Gösteren \\
\hline Dezavantaj & Basmakalıp / İğneleyici & Sinik / Lütufkar \\
\hline
\end{tabular}

Kaynak: Haeberle, Herzberg ve Hobbs, 2009: 18.

Sonuç olarak, her kuşağın kendine özgü deneyimleri, uzmanlığı, geleceği ve beklentileri vardır. Çalışma değerleri, tutumları, tercihleri, beklentileri, algıları ve davranışları arasındaki benzerliklerinin ayn tarihsel, ekonomik ve sosyal deneyimlerden kaynaklandığına inanılmaktadır (Kian ve Yusoff, 2012:397).

\section{Araştırmanın Amacı ve Hipotezler}

Mevcut çalışmanın temel amacı, kamu ve özel sektörde faaliyet yürüten işletmelerde çalışan $X$ ve Y kuşaklarına mensup bireylerin iş motivasyonlarında farklılaşma olup olmadığını belirlemeye çalışmaktır.

Bu noktada araştırma sorunsalları şu şekilde ifade edilebilir:

Kamu ve özel sektörde çalışan $X$ ve $Y$ kuşaklarına mensup bireylerin iş motivasyonlarında kuşaklara göre farklılaşma var mıdır?

Araştırmanın hipotezleri aşağıdaki gibidir:

- H1: X ve Y kuşakları ile iş motivasyonu alt boyutlarından motive olmama alt boyutu arasında anlamlı bir ilişki vardır.

- H2: X ve Y kuşakları ile iş motivasyonu alt boyutlarından dışsal düzenleme - sosyal alt boyutu arasında anlamlı bir ilişki vardır.

- H3: X ve Y kuşakları ile iş motivasyonu alt boyutlarından dışsal düzenleme - maddesel alt boyutu arasında anlamlı bir ilişki vardır.

- H4: $X$ ve $Y$ kuşakları ile iş motivasyonu alt boyutlarından içe yansıtılan düzenleme alt boyutu arasında anlamlı bir ilişki vardır.

- H5: X ve Y kuşakları ile iş motivasyonu alt boyutlarından kişisel düzenleme alt boyutu arasında anlamlı bir ilişki vardır.

- H6: $X$ ve $Y$ kuşakları ile iş motivasyonu alt boyutlarından içsel motivasyon alt boyutu arasında anlamlı bir ilişki vardır. 


\section{YÖNTEM}

Araştırmanın bu kısmında geçerlik ve güvenirlik analizi, araştırmanın çalışma evreni ve örneklemi, veri toplama yöntemi ve verilerin analizi başlıkları açıklanmıştır.

\section{Geçerlik ve Güvenirlik Analizi}

Bu çalışmada kullanılan anketin geçerlik güvenirlilik analizi sonucunda ölçeğin güvenirlilik katsayısı 0.767 olarak bulunmuştur. Bu değer anketin yeterli seviyede güvenilir olduğunu göstermektedir.

\section{Araştırmanın Evreni ve Örneklemi}

Araştırmanın evrenini Türkiye'de faaliyet gösteren kamu ve özel sektör çalışanları oluşturmaktadır. Araştırmanın örneklemini başta Ankara olmak üzere temsil yeteneğini elde etmek üzere farklı iller ve buradaki kamu özel çalışanları oluşturmaktadır. Tüm çalışanlara ulaşmak çok zor olduğundan kolayda örnekleme yöntemi kullanılmıştır. Araştırmada, 157 özel sektör ve 180 kamu sektöründe olmak üzere toplam 337 kişiye ulaşılmıştır. Hatalı ya da eksik olan 17 kayıt örneklemden çıkarılmıştır. Analizler 320 anket üzerinden gerçekleştirilmiştir.

\section{Veri Toplama Yöntemi ve Analizi}

Araştırmada, Gagne vd. (2014) tarafından yedi dilde (Fransızca, İngilizce, Felemenkçe, Norveççe, Almanca, Endonezya dili ve Çince) ve dokuz ülkede (Kanada, Belçika, Fransa, Senegal, Birleşik Krallık, Norveç, İsviçre, Çin ve Endonezya) geçerlemesi yapılan ve Çivilidağ ile Şekercioğlu tarafından Türk kültürüne uyarlaması gerçekleştirilen çok boyutlu iş motivasyonu ölçeği (ÇBIMÖ) kullanılmıştır. Veri toplama aracı olarak anket uygulanmıştır. Anket iki bölümden oluşmaktadır. İlk bölümde çalışılan sektör ve yaş bilgisinin yer aldığı demografik özellikler ve ikinci bölümde ise 19 ifadeden oluşan iş motivasyonu anketi yer almaktadır. Anket'te 3'lü Likert ölçeği kullanılmıştır. Ölçeğin değerlendirmesinde; 1 - Hiç Uygun Değil (not at all), 2 - Uygun (moderately) ve 3 - Tamamen Uygun (completely) şeklinde ifade edilmiştir. Bu ölçek, 3 temel boyut ve 5 alt boyut olmak üzere toplam 19 ifadeden oluşmaktadır.

Tablo 4. Çok Boyutlu İş Motivasyonun Temel Bileşenleri ve Alt Ölçekleri

\begin{tabular}{|l|c|c|}
\hline \multicolumn{1}{|c|}{ Çok Boyutlu Motivasyon Ölçeği } & Madde Sayısı & Madde Numarası \\
\hline Motive Olmama & 3 & $1,3,5$ \\
\hline Kontrollü Motivasyon & 3 & $7,9,11$ \\
\hline Dişsal Düzenleme - Sosyal & 3 & $13,15,17$ \\
\hline Dişsal Düzenleme - Maddesel & 4 & $14,16,18,19$ \\
\hline İçe Yansitılan Düzenleme & 3 & $8,10,12$ \\
\hline Özerk Motivasyon & 3 & $2,4,6$ \\
\hline Kişisel Düzenleme & \multicolumn{2}{|l|}{} \\
\hline İçsel Motivasyon
\end{tabular}


Veri analizleri için SPSS 24 paket programı ile bağımsız örneklem $\mathrm{t}$ testi ve frekans testi uygulanmıştır.

\section{BULGULAR}

Araştırmaya katılan $X$ ve $Y$ kuşağında yer alan çalışanların ankette yer alan ifadelere verdiği cevapların ortalamaları aşağıdaki tabloda yer almaktadır.

Tablo 5. Ölçekteki ifadelerin ortalama değerleri

\begin{tabular}{|c|c|c|}
\hline & $\begin{array}{c}\text { X Kuşağ1 } \\
\text { Ortalama } \\
(n=69)\end{array}$ & $\begin{array}{c}\text { Y Kuşağı } \\
\text { Ortalama } \\
(\mathrm{n}=251)\end{array}$ \\
\hline $\begin{array}{l}\text { 1. Zamanımı israf ettiğimi düşündüğüm için işimde çaba sarf } \\
\text { etmiyorum. }\end{array}$ & 1,46 & 1,42 \\
\hline 2. İlginç olduğu için işimde çaba sarf ediyorum. & 2,36 & 2,51 \\
\hline $\begin{array}{l}\text { 3. Çaba sarf etmeye değer olmadığını düşündüğüm için işimde } \\
\text { az çaba gösteriyorum. }\end{array}$ & 1,57 & 1,34 * \\
\hline 4. Heyecan verici olduğu için işimde çaba sarf ediyorum. & 2,64 & 2,76 \\
\hline $\begin{array}{l}\text { 5. İşim anlamsız olmasına rağmen neden hala bu işi yaptığımı } \\
\text { bilmiyorum. }\end{array}$ & $1,32 *$ & 1,35 \\
\hline 6. İşimi yaparken eğlendiğim için işimde çaba sarf ediyorum. & 2,70 & 2,84 \\
\hline $\begin{array}{l}\text { 7. Başkalarının (amir, meslektaş, aile vb.) onayını almak için } \\
\text { işimde çaba sarf ediyorum. }\end{array}$ & 1,71 & 1,80 \\
\hline 8. İşimde çaba sarf etmenin benim için özel bir anlamı var. & 2,80 & 2,88 \\
\hline $\begin{array}{l}\text { 9. Başkalarının (amir, meslektaş, aile vb.) bana daha fazla saygı } \\
\text { duyması için işimde çaba sarf ediyorum. }\end{array}$ & 2,00 & 2,14 \\
\hline $\begin{array}{l}\text { 10. Bu iş, kişisel değerlerimle uyumlu olduğu için işimde çaba } \\
\text { sarf ediyorum. }\end{array}$ & 2,77 & 2,88 \\
\hline $\begin{array}{l}\text { 11. Başkalarının (amir, meslektaş, aile vb.) bana yönelik } \\
\text { eleştirilerinden kaçınmak için işimde çaba sarf ediyorum. }\end{array}$ & 1,77 & 1,90 \\
\hline $\begin{array}{l}\text { 12. Bu işte çaba sarf etmenin kişisel olarak önemli olduğunu } \\
\text { düşündüğüm için işimde çaba gösteriyorum. }\end{array}$ & 2,81 & 2,90 \\
\hline $\begin{array}{l}\text { 13. Ancak işimde yeterince çaba sarf edersem başkaları (işveren, } \\
\text { amir vb.) beni ekonomik olarak ödüllendirirler. }\end{array}$ & 1,90 & 1,78 \\
\hline 14. İşimde çaba sarf ederim aksi halde, kendimi kötü hissederim. & 2,87 * & 2,96 * \\
\hline $\begin{array}{l}\text { 15. İşimde yeterince çaba sarf edersem başkaları (işveren, amir } \\
\text { vb.) bana daha fazla iş güvenliği sağlarlar. }\end{array}$ & 2,03 & 2,12 \\
\hline $\begin{array}{l}\text { 16. Şimdiki işimde çaba sarf ederim aksi halde, kendimi mahcup } \\
\text { hissederim, }\end{array}$ & 2,81 & 2,90 \\
\hline $\begin{array}{l}\text { 17. İşimde yeterince çaba sarf etmezsem işimi kaybetme riskim } \\
\text { olur. }\end{array}$ & 2,30 & 2,19 \\
\hline $\begin{array}{l}\text { 18. İşim, kendimle gurur duymamı sağladığı için işimde çaba sarf } \\
\text { ediyorum. }\end{array}$ & 2,77 & 2,89 \\
\hline $\begin{array}{l}\text { 19. Kendimi kanıtlamak zorunda olduğum için işimde çaba sarf } \\
\text { ediyorum. }\end{array}$ & 2,04 & 2,22 \\
\hline
\end{tabular}


Tablo 5 incelendiğinde araştırmaya katılan X kuşağı çalışanların en fazla 14. ifade olan "İşimde çaba sarf ederim aksi halde, kendimi kötü hissederim." ifadesini tercih ettiği görülmektedir. $X$ kuşağı çalışanlarının en az 5. ifade olan "İşim anlamsız olmasına rağmen neden hala bu işi yaptığımı bilmiyorum." ifadesi tercih ettiği görülmektedir.

Tablo 5 incelendiğinde araştırmaya katılan Y kuşağı çalışanların en fazla 14. ifade olan "İşimde çaba sarf ederim aksi halde, kendimi kötü hissederim." ifadesini tercih ettiği görülmektedir. Y kuşağı çalışanlarının en az 3. ifade olan "Çaba sarf etmeye değer olmadığını düşündüğüm için işimde az çaba gösteriyorum." ifadesi tercih ettiği görülmektedir.

Tablo 6 incelendiğinde araştırmaya katılan çalışanların genel olarak en fazla "kişisel düzenleme" iş motivasyonu alt boyutu ile motive olmaktadır. En az ise "Dışsal Düzenleme - Sosyal" iş motivasyonu alt boyutu ile motive olmaktadır. Motive olmama düzeyinin ise düşük seviyede olduğu görülmektedir.

Tablo 6. Çok Boyutlu İş Motivasyonu Boyutlarının Ortalama ve Standart Sapma Değerleri

\begin{tabular}{|l|c|c|c|}
\hline \multicolumn{1}{|c|}{ Çok Boyutlu Motivasyon Ölçeği } & $\mathbf{n}$ & Ortalama & Standart Sapma \\
\hline Motive Olmama & 320 & $\mathbf{1 , 3 9 3 6}$ &, 5536 \\
\hline Dişsal Düzenleme - Sosyal & 320 & 1,9221 &, 73207 \\
\hline Dişsal Düzenleme - Maddesel & 320 & 2,0426 &, 70852 \\
\hline İçe Yansıtılan Düzenleme & 320 & 2,7181 &, 32288 \\
\hline Kişisel Düzenleme & 320 & $\mathbf{2 , 8 6 7 1}$ &, 35695 \\
\hline İçsel Motivasyon & 320 & 2,6719 &, 51130 \\
\hline
\end{tabular}

Tablo 7. X ve Y Kuşakları ile İş Motivasyonu Boyutları Arasındaki İlişkiye İlişkin Bağımsız Örneklem T Testi Sonuçları

\begin{tabular}{|c|c|c|c|c|c|c|}
\hline İş Motivasyonu Boyutları & Kuşak & Ortalama & $\begin{array}{c}\text { Standart } \\
\text { Sapma }\end{array}$ & $\mathrm{t}$ & df & $\mathrm{p}$ \\
\hline \multirow{2}{*}{ Motive Olmama } & X Kuşağ & 1,4493 &, 59636 & \multirow{2}{*}{,947 } & \multirow{2}{*}{318} & \multirow{2}{*}{,344 } \\
\hline & Y Kuşağ & 1,3783 &, 53864 & & & \\
\hline \multirow{2}{*}{ Dişsal Düzenleme - Sosyal } & X Kuşağ & 1,8261 & 74887 & \multirow{2}{*}{$-1,231$} & \multirow{2}{*}{318} & \multirow{2}{*}{ 219 } \\
\hline & Y Kuşağ & 1,9484 & ,72670 & & & \\
\hline \multirow{2}{*}{ Dişsal Düzenleme - Maddesel } & X Kuşağ 1 & 2,0773 & 70744 & \multirow{2}{*}{,459 } & \multirow{2}{*}{318} & \multirow{2}{*}{647} \\
\hline & Y Kuşağı & 2,0331 & 70992 & & & \\
\hline \multirow{2}{*}{ İçe Yansitılan Düzenleme } & X Kuşağı & 2,6232 & ,39441 & \multirow{2}{*}{$-2,845$} & \multirow{2}{*}{318} & \multirow{2}{*}{$\begin{array}{l}\text {,005 } \\
*\end{array}$} \\
\hline & Y Kuşağ1 & 2,7440 & ,29600 & & & \\
\hline \multirow{2}{*}{ Kişisel Düzenleme } & X Kuşağ & 2,7923 & ,42818 & \multirow{2}{*}{$-1,989$} & \multirow{2}{*}{318} & \multirow{2}{*}{$\begin{array}{l}, 048 \\
*\end{array}$} \\
\hline & Y Kuşağ1 & 2,8876 & ,33289 & & & \\
\hline \multirow{2}{*}{ İçsel Motivasyon } & X Kuşağ & 2,5652 & 62441 & \multirow{2}{*}{$-2,006$} & \multirow{2}{*}{318} & \multirow{2}{*}{$\begin{array}{c}, 046 \\
*\end{array}$} \\
\hline & Y Kuşağı & 2,7011 & ,47296 & & & \\
\hline
\end{tabular}


$\mathrm{X}$ ve $\mathrm{Y}$ kuşakları ile iş motivasyonu boyutları arasındaki ilişkiyi incelemek için bağımsız örneklem $t$ testi yapılmıştır. Bu testin sonucunda elde edilen veriler Tablo 7'de yer almaktadır. Bu verilere göre içe yansitılan düzenleme, kişisel düzenleme ve içsel motivasyon boyutlarının $p$ değer 0,05'ten küçüktür. Bu durumda iş motivasyonu alt boyutlarından içe yansıtılan düzenleme, kişisel düzenleme ve içsel motivasyon boyutları ile $X$ ve $Y$ kuşakları arasında istatistiki olarak anlamı bir farklılık bulunmaktadır. Y kuşağının içe yansıtılan düzenleme, kişisel düzenleme ve içsel motivasyon düzeyleri $X$ kuşağına göre daha yüksektir. Tablo 7 de yer alan bilgilere göre $\mathrm{H} 1$, $\mathrm{H} 2$ ve $\mathrm{H} 3$ hipotezleri desteklenmemiştir. H4, $\mathrm{H} 5$ ve $\mathrm{H} 6$ hipotezleri desteklenmiştir.

\section{TARTIŞMA ve SONUÇ}

$X$ ve $Y$ kuşaklarına mensup çalışanların en yüksek seviyede tercih ettikleri "İşimde çaba sarf ederim aksi halde, kendimi kötü hissederim." ifadesi iş motivasyonu alt boyutlarından içe yansitılan düzenleme alt boyutunda yer almaktadır. Bu ifadenin en yüksek seviyede seçilmesi ankete katılan çalışanların genel olarak özsaygılarının yüksek olduğu anlamına gelebilmektedir. $X$ kuşağının en az seviyede tercih ettiği "İşim anlamsız olmasına rağmen neden hala bu işi yaptığımı bilmiyorum." ifadesi, Y kuşağının en az seviyede tercih ettiği "Çaba sarf etmeye değer olmadığını düşündüğüm için işimde az çaba gösteriyorum." ifadesi iş motivasyonu alt boyutlarından motive olmama alt boyutunda yer almaktadır. Bu ifadelerin en düşük seviyede seçilmesi ankete katılan çalışanların genel olarak gerçekleştirdikleri işe yönelik motivasyon eksikliklerinin düşük olduğu anlamına gelebilmektedir.

Tablo 6 incelendiğinde ise genel olarak çalışmaya katılan bireylerin motive olmama durumunun düşük seviyede olduğu ve iş motivasyonu kaynağının ise kişisel düzenleme alt boyutu olduğu sonucuna varılabilir. Başka bir ifade ile çalışmaya katılan bireyler genel olarak hedeflerin, değerlerin ve düzenlemelerin önemine göre motive olmaktadırlar. Bu motivasyon kaynağı klasik motivasyon teorisine göre dışsal motivasyon kaynağı olarak görülmektedir. Ancak öz belirleme kuramı ile birlikte özerk motivasyona dahil edilmiştir. Bu durum, sürekli olarak gerçekleştirilen bazı dışsal motivasyon kaynaklarının zamanla içselleştirilmesi ile özerk motivasyon kaynağı haline dönüşmesi olarak açıklanmaktadır. Bu çerçevede çalışmaya katılan bireyler genel olarak bir faaliyete olan ilgileriyle motive olduğu ifade edilebilir.

$\mathrm{X}$ ve $\mathrm{Y}$ kuşağına mensup bireylerin iş motivasyonu kaynaklarında bir farklılaşma olup olmadığına yönelik analizler yapılmıştır. Bu analizlerde $Y$ kuşağının içe yansıtılan düzenleme (özsaygı koşulu), kişisel düzenleme (hedeflerin, değerlerin ve düzenlemelerin önemi) ve içsel motivasyon (göreve duyulan ilgi ve keyif) düzeyleri $X$ kuşağına göre daha yüksek olarak bulunmuştur. Motive olmama, dışsal düzenleme (dişsal düzenleme - sosyal, dişsal düzenleme maddesel) alt boyutları ile $\mathrm{X}$ ve $\mathrm{Y}$ kuşağı arasında istatistiki olarak anlamlı bir ilişki bulunamamıştır.

Dışsal motivasyon kaynağının bir alt boyutu olan içe yansıtılan düzenleme, bir kişiye işi yapmayı istediği için değil bir yükümlülük duygusu dışında olmaktan korktuğu için davranışta bulunması noktasında ilham vermektedir. Başka bir ifade ile kişinin çevresinden gelecek tepkilerden çekindiği veya korktuğu için davranışta bulunmasıdır. Endişeyi teşvik ettiği için mümkünse bu motivasyon formundan kaçınmak gerekmektedir. Ayrıca kişi bu motivasyon biçimine yenik düştügünde, gerçekleştirdiği eylemleri hakkında olumlu ve kendinden emin hissetmesi zordur. Y kuşağında bu motivasyon düzeyinin daha yüksek çıkmasını Y kuşağının iş yaşamında kendini ispatlama isteği, başarılı olma isteği ve yükselme hırsı ile ilişkilendirilebilir. Barford ve Hester'in (2011) çalışmasında Y kuşağına mensup bireylerin yükselme olanaklarına X 
kuşağından daha fazla önem verdikleri sonucu, çalışmada elde edilen bu sonucu desteklemektedir.

Kuşaklararası farklılaşmanın olduğu bir diğer iş motivasyonu alt boyutu ise kişisel düzenlemedir. Kişi, kişisel olarak bir davranışın önemini belirlediyse ve bunu bir hedefe ulaşmada fayda sağladığı için kendi düzenlemesi olarak kabul ederse, kişisel düzenleme ile motive olur. Bu motivasyon formuyla, birey davranıştan zevk almak zorunda değildir ve acil bir ödül olması gerekmez. Kişi aynı zamanda suçluluk veya utançla motive olmaz. Sadece bir davranışın gelişimine faydalı olduğunu kabul eder ve bu davranışı benimser. Kişisel düzenleme, bireyin kişisel refahını ve arzularını etkileyen bir sonuca ulaşmak için kullanılır. Y kuşağının en belirgin özelliklerinden biri de herhangi bir durum veya sorunla karşılaştıklarında "neden" sorusuna cevap aramaları olarak ifade edilmektedir. Ayrıca $Y$ kuşağının her şeyi anlamaya çalışması, hırslı ve daha fazla sorgulayan yapısı $X$ kuşağına göre bu motivasyon kaynağının tercih seviyesinin daha yüksek olmasında etkili olduğu düşünülmektedir.

İçsel motivasyon, kişinin bir aktiviteye duyduğu ilgi ve zevkten kaynaklanmaktadır. Örneğin, bir kişi futbol oynamak için kendini motive hissediyorsa ve motivasyonu bir ödül ya da başka bir etkiden değil de oynarken yaşadığı sevinçten kaynaklanıyorsa, bu kişinin motivasyonu içseldir. İçsel motivasyon yaratıcılı̆̆ı ve yüksek kaliteli öğrenmeyi teşvik etmektedir. Ayrıca, içsel motivasyonu yüksek iş görenler, işlerini ilginç, eğlenceli ve ödüllendirici buldukları için çalışırlar. $Y$ kuşağının $X$ kuşağına göre daha yüksek içsel motivasyona sahip olmasını $Y$ kuşağının iş hayatı içerisinde var olmaya çalışmasından kaynaklanabileceği düşünülmektedir. Eskildsen vd., (2004), Ringer ve Garma (2006), Leahy vd., (2011), Yang (2011), Lourdes vd., (2011), Kian ve Yusoff (2012) ve Altınok (2019) çalışmaları X kuşağının içsel motivasyonun Y kuşağından daha yüksek olduğu soncuna varmıştır. Dolayısıyla, çalışmada elde edilen sonucu desteklememektedir.

Motive olmama ve dişsal motivasyon (dışsal düzenleme - sosyal, dışsal düzenleme - maddesel) alt boyutları ile $X$ ve $Y$ kuşağı arasında anlamalı bir ilişki bulunamamıştır. Acar (2014), Singh ve Gupta (2015), Helvacıoğlu ve Fırın (2019) çalışmaları bu sonucu desteklemektedir. Ancak literatürde $X$ ve $Y$ kuşağı arasında dışsal motivasyonun farklılaştı̆̆ına dair çalışmalar da bulunmaktadır. Jang (2008), Alley (2011), Barford ve Hester (2011), Lourdes (2011) ve Shea (2012) Y kuşağı mensuplarının dışsal motivasyonlarının $X$ kuşağı mensuplarından daha yüksek olduğunu ifade etmektedirler.

Elde edilen sonuçlar literatürdeki çalışmalardan farklılık göstermektedir. Bu tarz farklı sonuçların olması, bu alanda yapılan çalışmaların azlığı, farklı zaman dilimlerinde gerçekleştirilmiş olmaları ve ulaşılan kişilerden kaynaklanabilecek farklılıklardan dolayı doğaldır. Bu alanda yapılacak çalışmaların fazlalaşması ile birlikte genelleştirme yapılabilecek nitelikte bilgi oluşması muhtemeldir.

Çalışmada ülkemizin farklı bölgelerindeki kamu ve özel sektörde faaliyet gösteren kurum ve kuruluşlarda çalışan personel katılmıştır. Benzer çalışmayı yapacak araştırmacıların bölgesel, meslek grubu veya sektörel farklılıkları da dikkate alacak şekilde geniş bir örneklem üzerinde araştırma çalışması yapması önerilir.

\section{KAYNAKÇA}

Acar, A. B. (2014). Do Intrinsic and Extrinsic Motivation Factors Differ for Generation X and Generation Y? International Journal of Business and Social Science, 5(5), 12-20. 
Adıgüzel, O., Batur, H. Z., ve Ekşili, N. (2014). Kuşakların Değişen Yüzü Ve Y Kuşağı İle Ortaya Çıkan Yeni Çalışma Tarzı: Mobil Yakalılar. Süleyman Demirel Üniversitesi Sosyal Bilimler Enstitüsü Dergisi, 19, 165-182.

Akçakanat, T., Mücevher, M. H., ve Demirgil, Z. (2017). İşkolikliğin Kuşaklara Göre Karşılaştırılması: Süleyman Demirel Üniversitesi Akademisyenleri Üzerine Bir Araştırma. MANAS Sosyal Araştırmalar Dergisi, 6(3), 135-155.

Akgemci, T., ve Kalfaoğlu, S. (2018). X ve Y Kuşaklarının Kariyer Uyum Yetenek Düzeylerini Belirlemeye Yönelik Bir Araştırma: Lise Öğretmenleri Örneği. Nevşehir Hacı Bektaş Veli Üniversitesi SBE Dergisi, 8 (2), 231-247.

Akoğlu, D., ve Eroğlu, G. (2019). X ve Y Kuşaklarının İş-Yaşam Dengelerinin Demografik Faktörler Açısından İncelenmesi. Osmaniye Korkut Ata Üniversitesi İktisadi ve İdari Bilimler Fakültesi Dergisi, 3 (2), 221-243.

Al-Araimi, A. A. (2002). Exploratory study on employees' motivation in the omani private banking sector. Journal of Public Budgeting, Accounting ve Financial Management, 14(2), 208-220.

Altınok, D. (2019). X ve Y Kuşak Farklılıklarının İşe Bağlılık Ve Motive Eden Faktörler Açısından İncelenmesi. Sosyal Bilimler Akademi Dergisi, 2, 1-21.

Apridar, M. A. (2017). The Effect of Job Satisfaction and Work Motivation on Organizational Commitment and Organizational Citizenship Behavior in BNI in the Working Area of Bank Indonesia Lhokseumawe. In Proceedings of MICoMS, 1-5.

Aydın, G. Ç., ve Başol, O. (2014). X ve Y Kuşağı: Çalışmanın Anlamında Bir Değişme Var Mı? Electronic Journal of Vocational Colleges, 4(4), 1-15.

Bekmezci, M. (2017). Kuşakların Karşılaştırılması ve İş Dünyasında ' $Y$ ' Kuşağına Kuramsal Bir Bakış. Toros Üniversitesi İSBF sosyal Bilimler Dergisi, 4 (7), 101-111.

Boz, İ. T., ve Berber, F. (2017). Y Kuşağı Çalışanların Yönetimde Yaşadığı Problemlerin Tespitine Yönelik Bir Araştırma. Kafkas Üniversitesi İktisadi ve İdari Bilimler Fakültesi, 18(6), 525-536.

Çakar, N. D., ve Ceylan, A. (2005). İş Motivasyonunun Çalışan Bağlılığı ve İşten Ayrılma Eğilimi Üzerindeki Etkileri. Doğuş Üniversitesi Dergisi, 6 (1), 52-66.

Çivilidağ, A., ve Şekercioğlu, G. (2017). Çok Boyutlu İş Motivasyonu Ölçeğinin Türk Kültürüne Uyarlanmas1. Mediterranean Journal of Humanities, 7(1), 143-156.

Dharma, Y. (2017). The Effect of Work Motivation on the Employee Performance with Organization Citizenship Behavior as Intervening Variable at Bank Aceh Syariah. The Emerald Reach Proceedings Series, 1, 7-12.

Dipboye, R. L. (2018). Work Motivation. In The Emerald Review of Industrial and Organizational Psychology, 103-174. Emerald Publishing Limited.

Ekşili, N., ve Antalyalı, Ö. L. (2017). Türkiye'de Y Kuşağı Özelliklerini Belirlemeye Yönelik Bir Çalışma: Okul Yöneticileri Üzerine Bir Araştırma. Humanities Sciences (NWSAHS), 90-111.

Eskildsen, J. K., Kristensen, K., and Westlund, A. H. (2004). Work motivation and job satisfaction in the Nordic countries. Employee Relations, 26(2), 122 - 136.

Gagne, M., and Deci, E. L. (2005). Self-determination theory and work motivation. Journal of Organizational Behavior, 26(4), 331-362. 
Gagné, M., Forest, J., Vansteenkiste, M., Crevier-Braud, L., Broeck, V. D., Aspeli, A. K., and Roussel, P. (2014). The Multidimensional Work Motivation Scale: Validation evidence in seven languages and nine countries. European Journal of Work and Organizational Psychology, 24(2), 1-19.

Gökkaya, S., ve Türker, N. (2018). İş Motivasyonu İle İş Tatmini Üzerine Otel İşletmelerinde Karşılaştırmalı Bir Araştırma. İktisadi İdari ve Siyasal Araştırmalar Dergisi, 3(5), 12-28.

Göksel, A., ve Güneş, G. (2017). Kuşaklar Arasi Farklılaşma: X ve Y Kuşaklarının Örgütsel Sessizlik Davranışı Bağlamında Analizi. Gazi Üniversitesi İktisadi ve İdari Bilimler Fakültesi Dergisi, 19(3), 807-828.

Helvacıoğlu, E. T., ve Fırın, S. (2019). X ve Y Kuşağı Çalışanlarının Motivasyon Araçlarının Karşılaştırılması. Fırat Üniversitesi Sosyal Bilimler Dergisi, 29(2), 203-210.

Hong, J.-C., Yang, S.-D., Wang, L.-J., Chiou, E.-F., Su, F.-Y., and Huang, S.-L. (1995). Impact of employee benefits on work motivation and productivity. International Journal of Career Management, 7(6), 10-14.

Keleş, H. N. (2011). Y Kuşağı Çalışanlarının Motivasyon Profillerinin Belirlenmesine Yönelik Bir Araştırma. Organizasyon ve Yönetim Bilimleri Dergisi, 3 (2), 129-139.

Kian, T. S., and Yusoff, W. F. (2012). Generation X and Y And Their Work Motivation. Proceedings International Conference of Technology Management, Business and Entrepreneurship, (s. 396-407). Melaka, Malaysia.

Konakay, G. (2018). Y Kuşağı Değerlerinin Kariyer Tercihleri Açısından İncelenmesi. Girişimcilik ve Kalkınma Dergisi, 13(1), 79-92.

Kreitner, R., and Kinicki, A. (1988). Organizational Behavior (4ed). Boston: McGraw-hill.

Mert, G., ve Neslihanoglu, S. (2020). Y Kuşağının Kariyer AlgıSı ve Gelecek Beklentisi: Kocaeli Organize Sanayi Bölgesi Örneği. MANAS Sosyal Araştırmalar Dergisi, 9(2), 927-945.

Metin, S., ve Kızıldağ, D. (2017). X ve Y Kuşaklarının Kariyer Beklentilerinin Farklılaşması: Otomotiv Sektöründe Bir Araştırma. Mustafa Kemal Üniversitesi Sosyal Bilimler Enstitüsü Dergisi, 14 (40), 340-363.

Muhammad Al-Musadieq, N., Raharjo, K., Solimun, and Fernandes, A. A. (2018). The mediating effect of work motivation on the influence of job design and organizational culture against HR performance. Journal of Management Development, 37(6).

Murphy, P. K., and Alexander, P. A. (2000). A Motivated Exploration of Motivation Terminology. Contemporary Educational Psychology, 25(1), 3-53.

Nix, G. A., Ryan, R. M., Manly, J. B., and Deci, E. L. (1999). Revitalization through Self-Regulation: The Effects of Autonomous and Controlled Motivation on Happiness and Vitality. Journal of Experimental Social Psychology, 35(3), 266-284.

Orpen, C. (1997). The effects of formal mentoring on employee work motivation, organizational commitment and job performance. The Learning Organization, 4(2), 53-60.

Rahman, M. S., Daud, N. M., and Hassan, H. (2017). Generation " $X$ " and "Y" knowledge Sharing Behaviour: The Influence of Motivation and Intention on Non-Academic Staffs of Higher Learning Institutions. Journal of Applied Research in Higher Education, 9(2), 1-22.

Ryan, R. M., and Deci, E. L. (2000). Self-Determination Theory and the Facilitation of Intrinsic Motivation, Social Development, and Well-Being. American Psychologist, 55(1), 68-78. 
Saracel, N., Taşseven, Ö., ve Taşseven, Ö. (2016). Türkiye'de Çalışan Y Kuşağında İş TatminiMotivasyon İlişkisi. Social Sciences Research Journal, 5(1), 50-79.

Taş, H. Y., ve Kaçar, S. (2019). X, Y ve Z Kuşağı Çalışanlarının Yönetim Tarzları ve Bir İşletme Örneği. Uluslararası Toplum Araştırmaları Dergisi, 11(18), 644-675. 